\title{
The Impact of Technology Transfer through Foreign Direct Investment in Developing Nations: A Case Study in the United Arab Emirates
}

\author{
Batoul Modarress ${ }^{1}$, Abdolhossein Ansari $^{2}$ \& Emil Thies ${ }^{1}$ \\ ${ }^{1}$ College of Business, Zayed University, Abu Dhabi, United Arab Emirates \\ ${ }^{2}$ Albers School of Business and Economics, Seattle Universality, Seattle, Washington, USA \\ Correspondence: Batoul Modarress, College of Business, Zayed University, Abu Dhabi, United Arab Emirates. \\ E-mail: batoul.fathi@zu.ac.ae
}

Received: April 21, 2014

Accepted: May 5, 2014

Online Published: June 25, 2014

doi:10.5539/ijef.v6n7p108

URL: http://dx.doi.org/10.5539/ijef.v6n7p108

\begin{abstract}
Foreign investments have evolved over the past two decades to become the most critical business strategies for many companies. While developed countries have been the originators of more than $86 \%$ of foreign investment outflows, they receive only $65 \%$ of foreign inflows. By contrast, inward investments for developing countries have risen from $28 \%$ in 1990 to $53 \%$ in 2012 . This increase is the result of a growing perception among recipients that attracting FDI to their nations contributes to technology transfer, which enhances human capital formation, leading to reduced income inequality and sustainable economic growth. Therefore, the purpose of this paper is to examine the aforementioned perceptions in the United Arab Emirates (UAE), a developing nation. The study is based on a mail survey of 123 companies, personal interviews with 12 executives, and the review of documents from United Nations Conference on Trade and Development, Annual World Investment, IMF, OECD, UAE Ministry of Economy reports, and several local agencies. The findings indicate that there has been a significant transfer of technology to the UAE, which has had a positive impact on human capital formation. However, evidence of the relationships between technology transfer and income inequality or economic growth is inconclusive.
\end{abstract}

Keywords: technology transfer, income inequality, human capital formation

\section{Introduction}

Today, the geographical patterns of corporations are clustered around a multitude of connections to diverse businesses across borders, barriers of discipline, and jurisdictions. This reflects a growing complexity in the mode of corporate decision making in which the traditional make-or-buy decision is intertwined with Foreign Direct Investment (FDI) and Outsourcing (OS) (Lowe \& Taylor, 1998; Harrison, 1994; Gandolfi, 2009; Lonsdale \& Cox, 2000).

These two phenomena have become the most critical business strategies in developed nations for the past two decades. From 1990 to 2012, FDI flows increased more than eightfold from \$208 billion to \$1.8 trillion (United Nations, 2013). During the same period, almost $80 \%$ of manufacturing, $50 \%$ of IT, $43 \%$ of business processes, and 7\% of knowledge work were outsourced by more than $94 \%$ of the Fortune $\mathbf{5 0 0}$ companies (Schaltegger \& Wagner, 2012), and this is expected to grow by $4.65 \%$ over the period 2012-2016. While these two strategies are interspersed with numerous political and economic issues, they are presumed to be the ultimate proxy for global competitive success. Yet, they both require effective integration into the world's economy.

According to Helpman (1984), Markusen (1995), and Markusen and Venables (1999), companies integrate into the global economy by transferring work to external providers, or they may be resident in one country with a lasting interest in another country through Horizontal Foreign Direct Investment (HFDI) or Vertical Foreign Direct Investment (VFDI). HFDI duplicates home country-based operations with a more efficient value chain in a host country via mergers and acquisitions, whereas VFDI performs value-added activities by contracting out fragments of product operations (commonly called OS). An extension of VFDI that may involve a source country investing in an entirely new enterprise in a host country is referred to as Greenfield FDI, while exporting to a third nation is known as platform FDI. 
Still, the success of these investments in a host country is generally measured in terms of the amount of inflows and the number of projects based on two assumptions. First, the host government encourages foreign investments and offers incentives that are summed up as altering governments' foreign investment restrictions. According to the United Nations Conference on Trade and Development in the 1990s, more than $94 \%$ of 1,000 government investment regulations and laws were revised to improve FDI inflows (such as greater liberalization and the promotion and facilitation of foreign investment). In addition, from 2000 to 2007 more than 2,540 national regulatory bodies were altered to promote foreign investment (United Nations Conference on Trade and Development, 2008).

Second, in a relatively non-distorted and convivial environment, FDI and OS contribute to human capital formation, which leads to reduced income inequality and ultimately greater sustainable economic growth. The foundation of these assumptions is based on two mechanisms: the scale or the magnitude of investments and the level of technologies transferred that form the human accumulation of competencies, knowledge, and creativity to perform labor in order to produce economic value. The aggregate of economic value leads to the well-being of a population, which collectively results in reducing income inequality and rising sustainable economic growth (Baldwin et al., 1999; Kokko, 1996).

The extent to which these two mechanisms hold depend on a set of complex questions in developing nations:

i. How can we bridge the gap between existing technology and new technology transferred by foreign investors?

ii. Does the transferred technology have a positive impact on human capital formation?

iii. Does enhanced human capital formation reduce income inequality?

iv. Does a government positively influence the transfer of new technologies?

v. Is there a high level of consensus among government authorities regarding technology transfer?

vi. Does a significant regional-political risk hinder the transfer of new technologies?

Although the literature on various aspects of FDI is extensive, few investigations have aimed to answer these questions. The purpose of this study, therefore, is to investigate the aforementioned questions in the United Arab Emirates (UAE), a developing nation. This country is selected as it has undertaken rapid trade linearization with the objective of increasing the level of FDI in favor of human capital formation, income inequality and sustainable economic growth.

This paper is divided into four sections. The first section focuses on the distinction between FDI and OS to provide the key issues related to international investment and the transfer of technology in a multilateral trading system. Then, it presents the magnitude and rapid pace of FDI and OS followed by their proliferation in developing nations. Finally, this paper addresses the abovementioned research questions by testing six related hypotheses in the UAE.

\section{Comparison of FDI and OS}

Blinder (2009) believes that although FDI and OS are deeply intertwined in international trade and has become the most recurring schemes in developed, developing, and transition economies, their differences have received relatively little attention. By comparing these two business schemes, we can draw a number of conclusions:

1). FDI is an investment made by a company or entity based in one country into a company or entity based in another country. It takes different forms, such as cross-border mergers and acquisitions, franchising, joint ventures, license agreements (horizontal integration), setting up subassembly facilities or an entire supply chain (vertical integration), and sourcing subassemblies from foreign suppliers by ceasing the production of intermediate inputs, choosing instead to buy parts from unaffiliated firms located in foreign countries (Hornberger et al., 2011). HFDI can be a substitute for trade when production in the host country replaces exports, but it would be complementary to trade when a part of the production in the host country is shipped back to the home country (VFDI). VFDI can also be considered to be an alternative to OS, and this is divided into two types. Backward VFDI is when the overseas sales of a company serve as inputs for the downstream operations of domestic companies, whereas forward VFDI is when there is investment into a foreign industry that sells the output of a company's domestic production processes (International Monetary Fund, 2011). Nonetheless, OS is the manifestation of the increased fragmentation of existing standard products and services into their constituent parts. This is defined as decoupling, which allows companies to spread production across countries (Grossman \& Helpman, 2005; Modarress \& Ansari, 1990, 2008). 
2). FDI is an investment associated with a foreign company calculated as the sum of long-term and short-term equity capital that reflects the objective of establishing a permanent interest. Once FDI is established, increases can take the form of injections of additional equity capital, the reinvestment of earnings not distributed as dividends by subsidiaries or associated enterprises and undistributed branch profits, and various intercompany claims (such as the extension of suppliers' credits or loans). Additional capital is primarily driven by sharing resources (Levina \& Ross, 2003), maximizing profits, production process efficiency, strategic capability positioning (Grossman \& Helpman, 2003, 2005), access to low-wage low-skilled labor, improved product quality (Loh \& Venkatraman, 1995), increased global competition and faster responses to peaks and changes in production, and less investment in back-up equipment (Barney, 2010). By contrast, OS is a practice of having certain job functions carried out under contract with an outside supplier for fixed costs sale by the ordering company with low upfront investment (Blinder, 2009; Modarress et al., 2010).

3). An FDI corporate structure operates in the host country by setting up a subsidiary or associate company in the foreign land. By contrast, an OS corporate structure resides in the home country and is influenced by the scope of offshore suppliers' inputs into the final product, their resource networks, process knowledge, and technology to execute jobs efficiently and effectively.

4). FDI control and ownership is based on at least $10 \%$ of the voting power with the intention to influence the production, distribution, and business decisions of the investor in the host country. Markusen (1995) states that control, ownership, and bargaining power depend on either the extent of tangible assets such as patents and, technology or the magnitude of intangible assets (e.g., trade secrets and reputation for quality) that confers some valuable market power or cost advantage. Grossman and Helpman $(2002,2005)$ state that ownership is strongly associated with governments' statutory restrictions on the level of technology transferred. They also state that the level of technology replicates R\&D intensities, professional and technical skills, leading-edge products, and product differentiations. Nevertheless, OS companies have no control or ownership over their supplier in the host country and are neither in a partnership nor in a long-term relationship.

5). FDI assets are easily transferred to the host country, and foreign investors have legal rights to patent their products, trademarks, and capital knowledge as well as technical and associated services. Thus, the protection of intellectual property or intangible assets in the host country is more critical than OS. Dickinson (2005) and Reed (2005), in a study of 99 companies, observe that $64 \%$ of firms cite intellectual property as the concern for their company not OS since the protection of intellectual property is not granted. Emphasis is on jeopardizing the brand integrity by the licensee when the contract is terminated (Kokko, 1996; Barney, 2010). Although OS arrangements have the potential to involve product development, they require extensive training companies to avoid disclosing any intellectual property (Modarress \& Ansari, 2007).

6). While sharing operating costs and profit and making mutual contributions are common practices, HFDI reduces costs by duplicating the home-based products and processes in the host country. Grossman and Helpman (2003) state that FDI, costs of capital, transfer of technology, and knowledge capital are considerably higher than OS. While the primary focus of OS is on cost reduction, decisions are based on minimizing the production costs explicitly driven by transferring functions to entities beyond the perimeter of the principal organization (Modarress \& Ansari, 2010). Willem (2001) believes that cost is the crucial difference between FDI and OS.

7). FDI is based on a two-directional fund flow, namely inwards and outwards. Inward investments are reserves by non-resident investors in the reporting country, while outward investments are cross-border trades transferring funds to businesses with higher prospects for growth by direct investors resident in the reporting country. On the other hand, OS is a one-directional flow where the funds flow from home countries to suppliers for conducting a function (Feenstra, 1998).

8). FDI relates to a significant amount of tangible and intangible assets (Markusen, 1995); thus, firms hire fewer skilled workers to protect technology from spillover to the host country. This is the most commonly practiced means of foreign investment, which plays an important role as an engine of employment, technological development, productivity enhancement, economic intensification, and, more importantly, as an instrument of technology transfer from developed to developing countries. OS, on the other hand, requires higher skill workers compared with FDI, thus creating positive spillovers in host countries (Modarress \& Ansari, 2007).

9). Grossman and Helpman $(2002,2003)$ consider convenience to be a trade-off between OS and FDI. Since FDI's ultimate relationship with overseas partners is inundated with regulations linked to the legal framework of the host nation and contractual incompleteness, the final product and efficiency gained from OS are more convenient. Almonte and Bonassi (2004) support this conclusion, stating that final goods producers are sensitive to the degree of contract incompleteness in a host country, implying that OS is more advisable. 
10). The resilience of FDI to financial crises (Tong \& Wei, 2010) is much higher than that of OS. The flexibility of FDI flows during the Latin American debt crisis of the 1980s, Mexican crisis of 1994-1995, East Asian crisis of 1997-1998, and recent global economic crisis of 2008-2009 clearly document the lack of access of financially-constrained domestic firms to global capital markets.

These differences provide a broad perspective for initial investments and for the efficient utilization of the development process.

\section{Growth in FDI and OS}

The magnitude and rapid pace of FDI and OS have been well documented in the past two decades. Inward and outward FDI fluctuated throughout the 20th century. Worldwide annual FDI flows increased from $\$ 60$ billion in 1985 to $\$ 315$ billion in 1995 . This expansion continued to a record total of $\$ 2.09$ trillion in 2007 , resulting in a cumulative stock of nearly $\$ 18$ trillion (World Bank, 2009).

Consequently, with average growth at an annual rate of $5.4 \%$, manufacturing and service investments grew by more than 79,000 multinational companies, including 650 state-owned organizations. Their income increased from $\$ 184$ billion in 2000 to $\$ 580$ billion in 2008, an average annual growth of 9.7\% (UNCTAD, 2011).

However, in the wake of the global economic crisis, related to the Eurozone crisis, United States 'fiscal cliff', and various international FDI policy changes, flows came to a temporary halt in 2008 and 2009. Global inflows fell by $18 \%$ to $\$ 1.73$ trillion in 2008 and to less than $\$ 1$ trillion in 2009 , affecting all the major developed, developing, and transition economies. Based on data for 54 countries (20 developed and 34 developing countries), global inflows contracted by $49 \%$ in the first half of 2009 compared with the same period in 2008 . Sharp declines were recorded in all constituent components of FDI and OS. Cross-border mergers and acquisitions were the most affected with a 66\% decrease in 2009 compared with 2008. The number of international Greenfield projects also declined markedly (by 23\%).

A significant reduction in employment during this period was also seen. Worldwide employment by US multinational companies decreased by $0.4 \%$ in 2008 to 33.4 million workers. Employment in the United States by US parent companies decreased by $1.3 \%$ to 22.9 million workers as well (USDC, 2010). In 2009, international employment by US multinational companies decreased by $4.1 \%$ to 31.3 million workers, with decreases in both the United States and abroad. Employment in the United States by US parent companies decreased by $5.3 \%$ to 21.1 million workers, which mirrored the percentage change in total private-industry employment in the United States.

However, FDI global inflows rose by $16 \%$ in 2011, surpassing the 2005 to 2007 pre-crisis level to reach $\$ 1.2$ trillion. The world market also recorded 13,718 projects, an increase of $5.6 \%$ on 2010 , which created 2,265,006 jobs, $2.5 \%$ more than in 2010. Growth increased to $\$ 1.4$ trillion in 2012 (UNCTAD, 2012), while it is estimated that the value of cross-border mergers and acquisitions will reach $\$ 1.8$ trillion and $\$ 1.9$ trillion in 2013 and 2014, respectively (UNCTAD, 2012). The same pattern was seen in corporate employment, with estimated direct job creation increasing by $2.5 \%$ to 2.27 million in 2011, followed by a 3.5\% increase in 2012 and in 2013 .

OS has become equally lucrative, evolving from contractual preparations confined to the procurement of non-core competences to core competencies cutting across all industries (Lonsdale \& Cox, 2000). A study by the Center for Urban Economic Development finds that US imports of business, professional, and technical services associated with offshore OS increased by 77\% between 1997 and 2002. The study indicates that with the growth of a globally interconnected economy, firms constantly reassess their core competences in the new business context to rapidly respond to the global market (Palugod \& Palugod, 2011).

Rooted in these reassessments, the revenue of the global OS market expanded from $\$ 45.6$ billion in 2000 to $\$ 76.3$ billion in 2005 and grew to $\$ 95$ billion in 2008. The global network of multinational corporations generated approximately $\$ 16$ trillion from international production and foreign sales in 2010, which accounted for over a quarter of global GDP (World Bank, 2011).

Global OS revenue increased by $8 \%$ in 2010 and by 6\% in 2011. By 2012, more than $94 \%$ of the Fortune 500 companies, which accounted for $70 \%$ of global trade, outsourced $80 \%$ of manufacturing, $50 \%$ of IT, $43 \%$ of business processes, and 7\% of knowledge work. While developed countries had a 79\% market share (North America 53\%, United Kingdom 16\%, Europe 10\%), the share for developing nations was only $21 \%$ (India 9\%, Asia Pacific 5\%, Latin America 5\%, Middle East and North Africa 2\%), Prabhakar (2011).

\section{FDI Trends in Developing Nations}

The share of the world inflow of FDI in developing nations increased from 31.2\% during 1988-1992 to 35.5\% 
from 1993 to 1998 (UNCTAD, 2000) and it remained relatively resilient in 2012. During this period, the total reached $\$ 684$ billion, $\$ 130$ billion more than developed countries. These data show that while in 2007 developed nations represented 84\% (\$1.8 trillion) of global outflows and in 2009 about $81 \%$ ( $\$ 1.5$ trillion), developing nations contributed only $12-13 \%$ and transition economies $2.4 \%$ of total outflows in 2007 and $3.1 \%$ in 2009 . This represents an increase of 317\% from 1995 to 20009 (UNCTAD, 2008, 2011; Ernst \& Young's Attractiveness Survey, 2012). Table 1 shows the top 10 developing nations for world inflows.

Table 1. Top ten destinations of foreign investments in Middle East

\begin{tabular}{lccc}
\hline YEAR & 2011 & 2012 & \% Change \\
\hline Egypt & 44 & 1524 & $50 \%$ \\
Nigeria & 45 & 17 & $62 \%$ \\
Oman & 48 & 18 & $63 \%$ \\
Bahrain & 48 & 24 & $67 \%$ \\
Kenya & 55 & 29 & $42 \%$ \\
Qatar & 59 & 38 & $36 \%$ \\
Morocco & 70 & 48 & $31 \%$ \\
Saudi Arabia & 135 & 72 & $47 \%$ \\
South Africa & 154 & 74 & $52 \%$ \\
United Arab Emirates & 328 & 169 & $48 \%$ \\
\hline
\end{tabular}

Source: Data calculated using unctadstat.unctad.org. The Intelligence, 2013.

Primary FDI grew 12-fold, manufacturing increased by seven and half times, and services grew more than 17-fold from 1991 to 2007. The increase in the number of multinational corporations was complemented by an increase in the number of projects and total FDI value in the Middle East. The number of multinational organizations rose to more than 80,000 globally with more than 800,000 foreign affiliates spread across the world employing an estimated 69 million workers, who generated \$28 trillion in sales and \$7 trillion in value added. This represented a 9\% increase from 2010. According to the United Nation Investment Report (2012), high-income developing economies received more flows than any other development group for most of the period, in part because new investment is more productive in countries with vast markets, natural resources, a skilled workforce, and well-developed infrastructure.

FDI in developing nations and regions such as the Middle East rose rapidly by resource-seeking investors. With a vast supply of petroleum reserves and a total population of $394,460,000$, the number of annual FDI projects increased from 362 in 2003 to 1,070 in 2008. From 2003 to 2011, 6,740 projects worth $\$ 809.6$ billion were created, which contributed to the creation of more than 1.1 million jobs in the Middle East. Of these projects, $41 \%$ were carried out in the construction and energy sectors, $47 \%$ in the business services sector, and $12 \%$ in the manufacturing sector. According to FDI Intelligence (2012), the Middle East was ranked the number five destination in terms of number of FDI projects in the world behind large continents such as Europe with 4,639 projects, North America $(1,892)$, Latin America/Caribbean $(1,364)$, and Asia $(1,270)$.

During the 2010s, about 59\% of the total FDI inflow to the Middle East has thus far come from Western Europe and North America; however, the trend has been shifting towards intra-regional investments. As a result, this has first created a strong partner ranking, with the fourth largest investment in the region ahead of many developed countries such as France and Germany. Second, the UAE, Kuwait, and Qatar have been exerting an increasing influence on FDI projects with a rise in the share of total projects from $14 \%$ in 2007 to $24 \%$ in 2011 . Natural resources, especially petroleum, were the leading sector with an estimated $\$ 35$ billion capital investment, followed by metals and minerals with $\$ 27$ billion, which increased by $67 \%$ in 2010 , and construction. In terms of project distribution, financial and business services were the top sector, accounting for $33 \%$ of all projects recorded in the Middle East, with a growth of 3\% in 2011. Yet, minerals were the leading sector with an estimated 57,000 jobs created (38\% of growth in 2011).

\subsection{Growth in Gulf Cooperation Council (GCC) Countries}

In 2011, the political turmoil that resulted from the Arab Spring uprisings in the Middle East led to $80 \%$ losses in the volume of FDI in Libya, $80 \%$ in Yemen, 29\%, in Egypt, 26\%, in Syria, and 14\% in Tunisia. As a result, GCC countries became the leading destination for projects. Since 2003 , about $79 \%$ of projects in the Middle East, which represents $62 \%$ of total value and $65 \%$ of jobs, have moved to GCC countries including Bahrain, Kuwait, 
Oman, Qatar, Saudi Arabia, and the UAE. From 2003 to 2010 alone, inflows into GCC increased by over 3800\%, outpacing developed nations by a significant margin as shown in Table 2. The inflow trend continued to increase in 2011 and 2012 (Office of The Chief Economist, The World Bank, Report No. 57517, and Economic Integration in the GCC, 2010). Among GCC nations, the UAE was the most attractive country for investments, ranking 38th globally, followed by Kuwait (41st), Bahrain (43rd), Qatar (49th), Oman (54th), and Saudi Arabia (56th).

Table 2. Inward for GCC (in millions of US dollars), 2003-2011

\begin{tabular}{llllllllll}
\hline Country & 2003 & 2004 & 2005 & 2006 & 2007 & 2008 & 2009 & 2010 & 2011 \\
\hline Bahrain & 6,720 & 7,354 & 8,276 & 11,191 & 12,947 & 14,741 & 14,998 & 15,154 & 15,935 \\
Kuwait & 384 & 408 & 645 & 773 & 945 & 8,722 & 10,332 & 11,235 & 10,765 \\
Oman & 2417 & 2460 & 4132 & 5720 & 9152 & 11680 & 13142 & 14217 & 15005 \\
Qatar & 3456 & 4655 & 7155 & 10655 & 15355 & 17769 & 25894 & 30564 & 30477 \\
Saudi & 18512 & 20454 & 33535 & 50659 & 73480 & 110200 & 142300 & 170450 & 186850 \\
UAE & 6604 & 16608 & 27508 & 40314 & 54500 & 68224 & 72227 & 77727 & 85406 \\
\hline
\end{tabular}

Sources: UNCTAD (http://unctadstat.unctad.org).

\subsection{Growth in the UAE}

In 2004, FDI inflows into the UAE were about \$9 billion and the IMF projected $\$ 10.3$ billion for 2005 . According to the 2005 UNCTAD Inward FDI Performance Index, the UAE ranked 34th out of 141 other countries worldwide and number five among Arab nations in attracting FDI. The UAE inflows grew at an average annual rate of $64 \%$, from $\$ 0.5$ billion in 2000 to $\$ 12.6$ billion in 2006 .

In 2010, the UAE attracted 368 FDI projects, which was 13.9\% higher than that in the previous year and resulted in creating 22,166 additional jobs. While Dubai and Abu Dhabi, the largest Emirates, are the leading Emirates, the country's attractiveness as an FDI destination stems from its growing infrastructure, strategic location, and access to the growing African and Middle Eastern markets.

In the past, FDI has been directed towards the development of petroleum resources (representing $73 \%$ in 2005). However, the strategic need to further reduce economic dependence on the oil and gas sector through economic diversification has created additional business opportunities. For example, in terms of value and number of projects, business manufacturing accounted for $20 \%$, trade $17 \%$, business services $16 \%$, real estate $12 \%$, and other services $11 \%$ followed by transport, storage, and communication at $10 \%$ and financial at $9 \%$. The government services sector has also made an integral contribution to the UAE's non-oil GDP (11\%). With regards to manufacturing, the primary producer is Abu Dhabi, which represents almost half of the UAE's manufacturing sector, followed closely by Dubai with a share of 33\% and Sharjah with $11 \%$.

Despite a sharp decline in most other Arab countries because of political unrest and the global downturn, increasingly larger shares of FDI have been allocated to various sectors, which reflect the diversity of the UAE, and this has continued to increase. Capital flows into the UAE surged by nearly $40 \%$ to more than $\$ 7$ billion in 2011. In 2012, UAE inflows were $\$ 8.2$ billion, which represents $23.7 \%$ of its GDP. The significant difference between GCC and the rest of the developing nations was the amount of FDI outflows to developed countries. While the amount of inflows surpassed outflows from 2000 to 2011, the UAE matched inflows with outflows in 2012. The Abu Dhabi Investment Authority manages more than $\$ 627$ billion in sovereign funds (third in the world after Norway and Saudi Arabia), comprising financial assets, real estate, and other investments in foreign countries. In 2013, the UAE claimed an even higher position in the latest AT Kearney Global FDI Confidence Index as a result of the growing perception among UAE authorities that attracting FDI contributes to technology transfer, which enhances human capital formation, leading to reduced income inequality and a diversified economy.

\section{Purpose and Methodology}

The primary purpose of this study is to investigate and describe the perceptions among regulators that attracting FDI contributes to technology transfer, which adds to the formation of human capital, leading to reduced income inequality and a diversified economy. The study, as a consequence, is exploratory and qualitative in nature. Three citations are most often offered in the organizational literature to support a given study's methodological justification (Glaser \& Strauss, 1967; Eisenhardt, 1989; Yin, 1984). These authors all suggest that qualitative 
methods should be used in research areas (e.g., FDI in a developing country ) that are pre-paradigmatic in nature, namely no theoretical framework from which to make predictive hypotheses, per se, have been advanced in the literature. However, the following six general propositions can be advanced from the literature regarding technology transfer to the UAE:

\section{P1: Significant effort is required to bridge the gap between the existing technology and technology transfer to} the UAE.

P2: The technology transferred has had a positive impact on human capital formation in the UAE.

P3: The technology transferred has reduced income inequality in the UAE.

P4: There has been a positive influence on transfer technology through UAE government policies.

P5: There has been a high level of consensus among UAE authorities regarding technology transfer.

P6. Significant regional and political risks exist that hinder technology transfer to the UAE.

Three primary methods of data collection were employed in this study. First, we reviewed internal documents obtained from the United Nations Conference on Trade and Development, Annual World Investment studies, data from the IMF, the OECD, data compiled by the UAE Ministry of Economy, and several local agencies and internal reports produced by private corporations. Second, 14 qualitative interviews were conducted with officials and executives in private sectors in the companies listed in Table 3.

Table 3. Company name

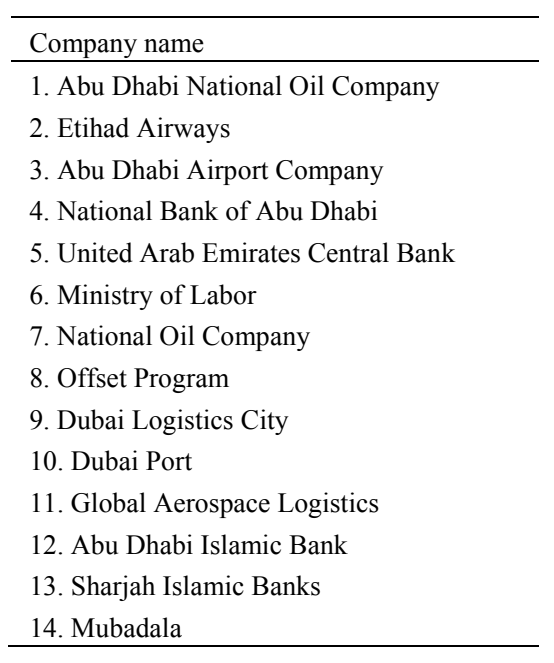

Finally, the information from the interviews was used to design a six-part field survey questionnaire to gather more in-depth information to assess the stated propositions. In January 2013, 200 questionnaires were sent to 123 public and private companies. Respondents were asked to voluntarily complete the questionnaire and were given assurance of anonymity (i.e., individual responses would not be revealed, only aggregate numbers). Complete and usable questionnaires were returned by 123 respondents, which represented a response rate of $61.5 \%$. Approximately $43 \%$ of respondents were supervisors; $18 \%$ were second-level management, $27 \%$ were directors; and $12 \%$ were senior executives of their business units. Based on the annual revenues, the company size was grouped into three categories: annual revenues less than $\$ 100$ million; revenues between $\$ 100$ million to $\$ 500$ million; and revenues greater than $\$ 500$ million, as shown in Table 4. The majority (52\%) of respondents had annual revenues of less than $\$ 100$ million; $25 \%$ reported revenues between $\$ 100$ million and $\$ 500$ million, and about $23 \%$ reported revenues greater than $\$ 500$ million.

Table 4. Company size

\begin{tabular}{lc}
\hline Revenues & Percentage of Respondents $(\%)$ \\
\hline Less than \$100 million & 52 \\
\$100 million $-\$ 500$ million & 25 \\
Greater than $\$ 500$ million & 23 \\
\hline
\end{tabular}




\section{Results and Discussion}

P1: Significant effort is required to bridge the gap between the existing technology and technology transfer to the UAE.

According to Philip et al. (2001), advancement in technical areas depends on a number of factors including future regional economic arrangements, international intellectual property and protection, the character of future multinational corporations, and the role and amount of public and private sector R\&D investment.

The survey findings show that significant effort is required to bridge the gap between the existing technology in the UAE and technology transfer by foreign investors. This proposition is the greatest concern cited by respondents in the study. Table 5 shows the number of respondents that numerically rated the significance of each proposition using a scale of 1 ('low'), 2 ('moderate'), and 3 ('significant').

Table 5. Responses to the six propositions

\begin{tabular}{|c|c|c|c|c|}
\hline Degree of Importance a Propositions & $\begin{array}{c}\text { Number of } \\
\text { Respondents }(n=123)\end{array}$ & $1(\%)$ & $2(\%)$ & $3(\%)$ \\
\hline (P1) There is a difference between existing technology and technology transfer & 97 & 4 & 12 & 84 \\
\hline (P2) There is a positive impact on human capital formation through technology transfer & 100 & 4 & 10 & 77 \\
\hline (P3) There is a positive impact on income inequality through technology transfer & 98 & 24 & 5 & 71 \\
\hline (P4) The UAE government has a positive influence on technology transfer & 96 & 8 & 27 & 65 \\
\hline (P5) There is a high level of consensus in the UAE about technology transfer by FDI & 95 & 34 & 43 & 23 \\
\hline (P6) There are political challenges facing foreign investors in the UAE & 95 & 14 & 32 & 54 \\
\hline
\end{tabular}

a Categories: (1) 'Low', (2) 'Moderate', and (3) 'Significant'.

Nearly $84 \%$ of survey respondents indicated that without doubt there is a significant difference between the existing technology in the UAE and the new technology transfer, while $12 \%$ stated a 'moderate' difference. Only $4 \%$ of respondents indicated a 'low' difference (Table 5). Thus, the difference between existing technology and technology transfer is supported $(P 1)$.

The interviews with executives showed that during the past decade, the UAE has made significant technological progress but mainly focused within universities and government organizations. However, the technology gap between UAE partners and investors remains wide $(P 1)$. They believe that UAE partners have expanded their capabilities through the transfer and diffusion of technologies in different areas through four channels: (i) vertical linkages (backward and forward) with suppliers; (ii) horizontal linkages with aerospace companies; (iii) the migration of skilled labor; and (iv) the internationalization of R\&D (Modarress and Ansari, 1990).

According to the executives, technology developments are divided into four areas: energy, materials, ICT, and genetics. They stated that technology transfer during the past decade has brought the UAE highly effective and economically productive dependencies on successive waves of ICT, energy sources of petroleum, natural gas, and to some degree nuclear power. Alternatively, $49 \%$ of respondents (Figure 1) indicated that the UAE is more advanced in energy technology. Still, $42 \%$ specified that more development has been made, while $9 \%$ believed there has not been a noticeable development in energy technology advancements. In ICT, $76 \%$ believed that there has been a significant development in the UAE, while 17\% indicated reasonable development and $7 \%$ claimed that the development has not been noticeable. 


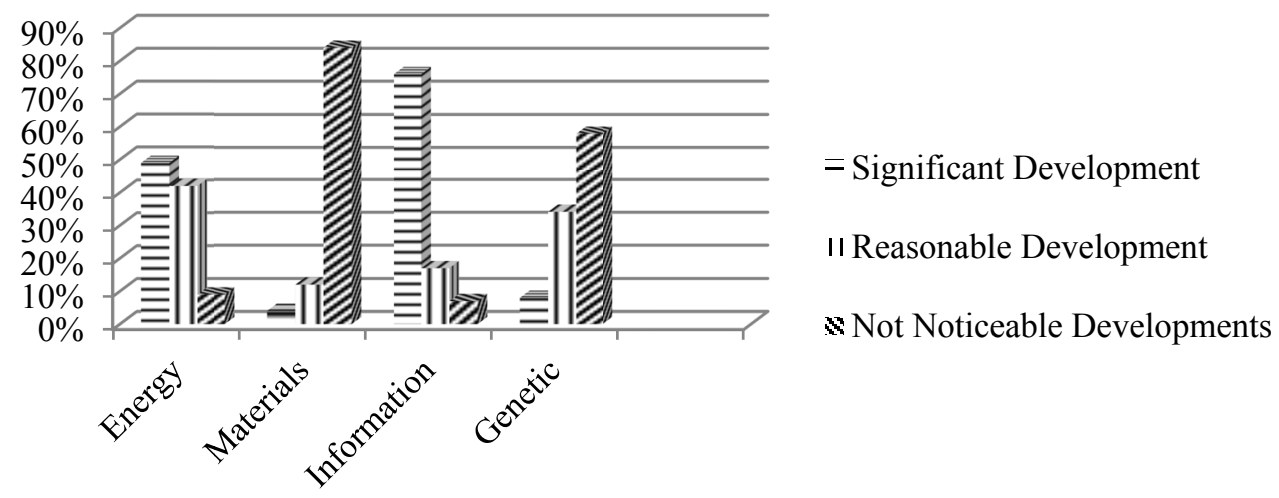

Figure 1. Technology development in UAE, 2002-2012

However, by comparing technology development in materials and genetics with energy and ICT, according to respondents, the developments have not been noticeable. For example, the executives in the UAE's aerospace sector emphasized that aircraft components are complex and require sets of resilient materials, advanced technology, and ICT necessary for design, production, and testing. Moreover, higher performance, speed, power consumption, and cost are key factors, while visibility, interoperability, and information sharing are also necessary. Hence, the UAE has had to change its existing technological structure as well as train all employees on this new technology and its procedures and processes. The executives explained that there are three steps to changing their technological structure, namely developing a primary roadmap, identifying the product that will be the focus of the roadmap, and periodically reviewing and updating the technology.

The Strata-Mubadela Aerospace Company owned by the UAE government, which is a partner with the Boeing Company for the 787 Dreamliner, first started building the infrastructure for the primary roadmap to define the scope and boundaries of the project requirements defined by Boeing. This step included identifying the necessary hardware and software to meet the project requirements. Boeing, for example, requires Mubadela Aerospace to comply with its hardware and software requirements for accessing, sharing, and viewing information.

The second step involved the design and development of technology based on the requirements outlined in purchasing accessible technology and assistive technology products. Subsequently, this involved identifying the internal technology systems that needed to be updated to increase accessibility.

Third was the periodic review to maintain the technology and create strong partnerships among the various groups of suppliers and customers. Fourth, increasing awareness at all levels among employees related to the availability and accessibility of new technologies and to providing training in design, manufacturing, maintenance, and repair.

\section{P2: Technology transfer has had a positive impact on human capital formation in the UAE.}

In general, human capital development represents the skills embodied in human beings based on their ability to absorb knowledge on transferred technologies. Schultz $(1961,1975)$ defines positive technology transfer as the movement or flow of technical knowledge, information, designs, prototypes, materials, inventions, and trade secrets from their creator to users to be applied and exploited for the purpose of enhancing human knowledge.

Human capital formation is divided into skilled and less skilled categories. Dunning (1993) states that efficiency-seeking investors require less training and that asset-seeking investment is perceived to be less beneficial to human capital formation than market-seeking investment. However, the adoption of new technologies requires extensive training and inputs from the labor force. High-level capital goods need to be combined with labor that is able to understand and work with the new technology. Therefore, technological spillover is possible only when a certain minimum level of skilled human capital is available in the host country (Modarress et al., 2013).

The executives interviewed stated that while the proliferation of technologies in the UAE has overcome the obstacles of time and space during the past decade, it has created a fertile environment for the formation of human capital. Human capital formation in the UAE seems to be the result of government policies designed to attract FDI to the country. Once individuals are employed by multinational corporations' subsidiaries, their 
knowledge is enhanced further through training on the application of advanced technologies in areas such as aerospace and petroleum. The results of the survey showed that approximately $77 \%$ of respondents indicated that they experienced a significant positive impact on human capital formation only after technology transfer through FDI. About $10 \%$ reported this to be moderate impact and only $4 \%$ a low impact, as shown in Figure 2 . Thus, technology transfer has had a positive impact on human capital formation, supporting $P 2$.

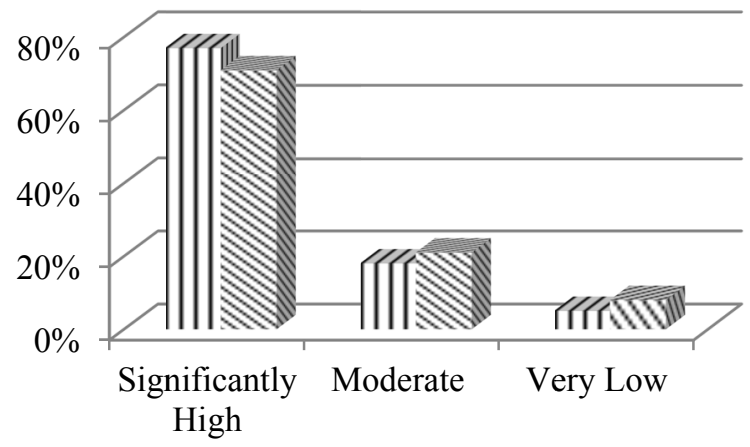

II Impact Human Capital Formation

\% Reduces Income Inequality

Figure 2. Impact of technology transfer on human capital and income inequality

Several executives also stated that foreign affiliates diffuse technology and skills to domestic suppliers, customers, and entities with which they have direct and indirect dealings. In particular, backward linkages between foreign affiliates and domestic firms are important for enhancing technology dissemination. To ensure that local inputs meet their stringent technical requirements, foreign affiliates often provide local suppliers not just with specifications but also with assistance in order to increase their technological capabilities. Such assistance tends to be more prominent in certain industries such as petroleum, aerospace, and manufacturing, where knowledge transfer has had a positive impact on suppliers' competitiveness. This is one of the main reasons for the UAE rising in the International Human Development Index from 0.443 in 1980 to 0.818 in 2013 (41st out of 187 countries). This finding suggests that technology transfer has had a positive impact on human capital formation in the UAE, especially with regards to labor productivity in the petroleum, finance, real estate, transportation, and manufacturing sectors $(P 2)$.

\section{P3: The technology transferred has reduced income inequality in the UAE.}

In theory, the relationship between FDI and income inequality has been explained as the modernization hypothesis and dependency hypothesis. The modernization hypothesis treats foreign capital and domestic capital as homogeneous goods. The inflow of foreign capital attracts labor to a host country, adds to gross domestic investment, and fosters economic growth. Growth in turn leads to a reduction in income inequality (Lin \& Tomaskovic-Devey, 2011). The UAE Department of Labor (2012) supports this hypothesis by reporting that expatriates comprise about $96 \%$ of workers in the country. These workers maintain close ties to their home countries and send back remittances to the country of their origin. This reached $\$ 30$ billion in 2012 (UAE Exchange Center, 2013). According to the World Bank (2012), the value of remittances transferred among developing nations more than quadrupled from 2002 to 2012.

The dependency hypothesis, on the other hand, argues that foreign investments are harmful to developing economic growth by extracting labor and surpluses from the third world. While FDI attracts labor, it distorts developing countries' domestic labor skills and the formation of human capital, thereby increasing income inequality (Hein, 1992). Consequently, socially and economically, FDI translates into greater disparities of wealth, as $17 \%$ of the world's population consumes $80 \%$ of its resources, leaving almost five billion people to live on the remaining $20 \%$. Specifically, 1.2 billion of the world's population now lives on less that $\$ 1$ per day, another 1.8 billion on less than $\$ 2$ per day, 800 million are hungry every day, and more than 60,000 humans die each day from hunger (United Nations Human Development Report, 2012).

In this study, $71 \%$ of survey respondents rated the impact of technology transfer on income inequality in the UAE to be significantly high. The interviews also showed that technology transfer stimulated by multinational companies reduces income inequality, which supports $P 3$. Yet, many executives, during the interviews, commented that the diffusion of technology has a negative correlation with income growth among $90 \%$ of the 
population and a positive correlation with income growth among richer groups. In other words, it helps the rich get richer, while the poor get poorer. About $5 \%$ of respondents considered technology transfer to have had a moderate impact on income inequality. Still, $24 \%$ said that technology transfer has had a low impact on income inequality in the country, as shown in Figure 2.

The executives also believed that surging oil prices, which generate more than $70 \%$ of nominal income, have led to a turnaround in the UAE's economic fortunes and a return to some of the big spending that has characterized the country since the 1970s. Between 1973 and 2009, the UAE's GDP increased from $\$ 2,800$ billion to more than $\$ 266,000$ billion and it is estimated to reach $\$ 358.9$ billion by 2014 with a per capita GDP value of $\$ 64,840$ (Ministry of Finance and Industry, 2008). The IMF (2008) ranked the country's per capita income 15th in the world in 2007, while the Central Intelligence Agency ranked its per capita GDP $14^{\text {th }}$ in the world and second in GCC after Qatar in 2009. Despite this revenue, about $10 \%$ of the population falls into the lowest household income group, with another $10 \%$ in the highest income group. In conclusion, the result does not fully support the influence of foreign investment on labor income inequality in the UAE (P3).

P4: There has been a positive influence on transfer technology through UAE government policies.

According to neoclassical economic theory, business entities are driven by profit incentives that result from efficiency and economies of scale. Country enticements are the most convincing factors that influence flows. The UAE's inducements are grouped into seven main categories: 1) Infrastructure incentives, especially transportation and communication networks; 2) Resource endowments, including natural and human resources; 3) Sizeable GDP, measured by GDP per capita and sustained growth in these markets measured by the growth rates of GDP; 4) Macroeconomic stability, signified by stable exchange rates and low rates of inflation; 5) Government stability; 6) The government's favorable policies and fiscal and monetary incentives in the form of tax concessions; and 7) Regional groupings and preferential trading arrangements between prospective recipients of FDI.

USAID (2005) reports that the UAE attracts investors to fulfill four objectives: market seeking, resource seeking, and strategic asset seeking. The most important motives are the size of the regional market, the extent of host country exports, and its integration with neighboring and international countries (Markusen, 1995). Under resource seeking, the markets previously served by companies are protected by government restrictions and trade barriers. These types of business relations could easily be related to OS since it requires low-cost and specialized labor, while VFDI is provoked by their need to access cheap energy. Finally, strategic asset seeking occurs when companies accept investments, joint ventures, acquisitions, or alliances to promote their long-term strategic objectives. The main difference between resource seeking and strategic asset seeking is that the company aims to obtain certain foreign resources to improve the quality of its offering, provide new features to its products, and significantly increase its market share (Lim, 2005).

However, the UAE government enforces restrictions subject to its legal framework, which may hinder FDI. The areas of restrictions are: 1) General restraints on entry, where at least $51 \%$ of the share of the company must be held in the Emirates; 2) Distributions, expatriates are excluded from distributions; 3) Landownership restrictions, limitations on expatriates' ability to purchase land; and 4) Labor market restrictions. This includes local agent requirements in government procurement, restrictions on lending to expatriates, no business outside free zones, blocking capital and profit repatriation, and discriminatory tax treatment. The profit of foreign banks is also subject to a profit tax levied by local authorities at an annual rate of $20 \%$ (Documents by Central Bank of Abu Dhabi; Department of Labor, and Ministry of Interior).

The majority of executives interviewed indicated that government policy plays a critical role in the transfer of technology. About $65 \%$ of respondents agreed that government policies have a significant positive influence on technology transfer (P4). They provided a list of 14 government-supported incentives (Table 6) for attracting technology transfer. Moreover, new investment laws and regulations are evolving and these are expected to become more conducive to foreign investment and new technology diffusion. The executives also mentioned the establishment of Free Zones and a Logistics City as part of the strategy to attract more investment in order to diversify the UAE economy. This strategy has contributed to 33\% of Dubai's GDP, with 19,000 firms and 26,000 employees. Free-zone employees, who contribute to export and re-export figures, were valued at $\$ 5.6$ billion in January 2012, an increase of $4.7 \%$ in comparison with January 2011; however, they are confined to low-tech highly labor-intensive activities. Low skilled jobs are also allocated to repetitive manufacturing, aluminum, cement, logistics, shipping, and trades. 
Table 6. Factors attracting

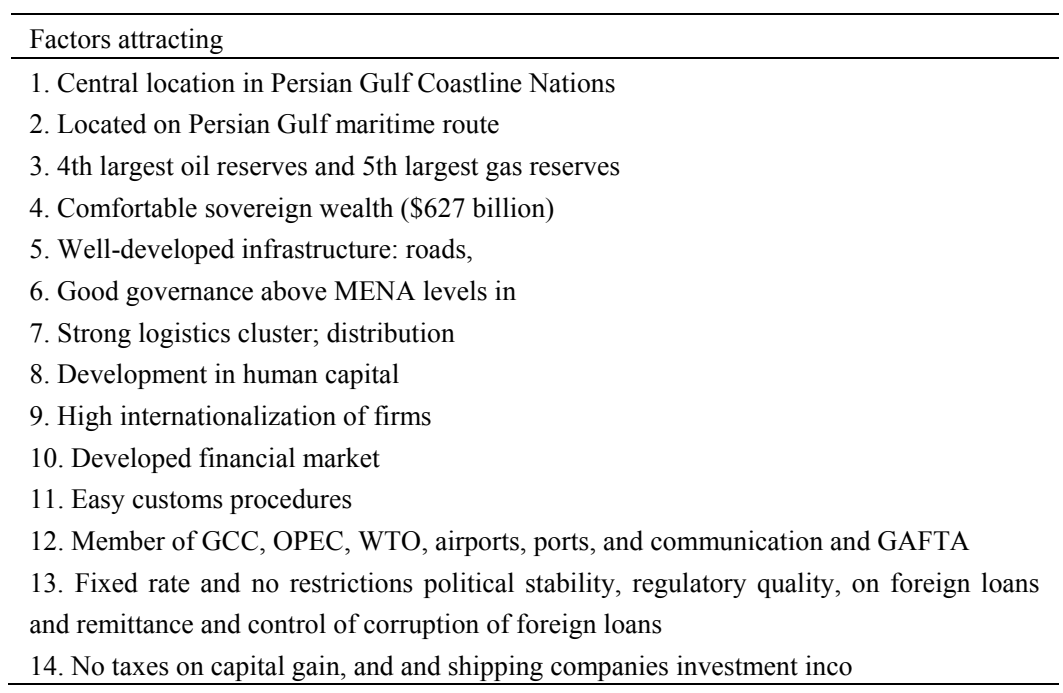

About $27 \%$ of respondents rated that the government has a moderate influence on technology transfer, while $8 \%$ believed that it has a low influence. The executives also listed 25 factors (Table 7) that hinder foreign investment. Therefore, investors face numerous existing government restrictions that encumber foreign investment in the UAE ( $P 4)$. In particular, government restrictions concern landownership, limited business ownership, restrictions on natural resources, critical infrastructure, and military projects that require government review and approval.

Table 7. Factors hindering

1. Lack of innovation capability

2. Low female participation in the workforce

3. Low nationals with the skills demanded by the private sector, national reliance on government support

4. Burdensome rules ( $49 \%$ to $51 \%$ ) for starting business and restrictions on entry by foreign direct investors

5. No governing compensation if expropriations were to occur

6. No insolvency laws; no competition laws; no standard accounting

7. Limited investor protection, no right to private ownership and establishment, limited access to financial resources above 15 million AED

8. Economic reliance on hydrocarbon exports

9. International sanctions on Iran,

10. struggles to insulate itself from regional disruption triggered by the Iranian nuclear power

11. Global financial crisis and the UAE Dirham tie to the US\$

12. Weak convertor industries

13. Shallow cluster of R\&D

14. Bureaucratic management and a lack of transparency in government

15. The role of the state in the economy and price control

16. Societal instability due to the disproportionately high ratio of foreign labor and income inequality

17. Lack of commitment to international environment and labor rules

18. Political violence in neighboring countries

19. Lack of commitment to bilateral investment rules, subtle expropriation of gained returns

20. Hostile attitudes of elites and society towards the FDIs

21. Internal terrorist attacks, conflicts with foreign workers, and the increasing number of radicalized Emirati youth

22. Reluctance to reveal reliable information

23. Limited capacity in ports and handling expected -large number of containers for petrochemical products (400 containers per week)

24. Costly supply and distribution services

25. Secrecy of most political and economic activities

Furthermore, according to the executives, the three most problematic factors for highly-intensive labor investments (such as manufacturing) are 'restrictive labor regulations', 'access to financing', and 'an inadequately educated workforce'. This is particularly true for manufacturing, port operations, and maintenance. In conclusion, 
P4 is not fully supported.

\section{P5: There has been a high level of consensus among UAE authorities regarding technology transfer.}

Technology transfer through FDI has raised serious concerns and doubts among top UAE management (Modarress \& Ansari, 2007). Only 23\% of respondents indicated a significant level of consensus among UAE authorities regarding technology transfer by FDI compared with $43 \%$ that expressed a moderate level and $34 \%$ a low level.

The executives mentioned that UAE authorities are concerned about the implications of having an international investment agreement that lays down common standards for national investment policies and which requires each signatory to be bound to its rules. Being bound to national policies under a multilateral agreement would be viewed by the country as going even further towards pre-empting a country's right to manage inflows in the short-term, medium-term, and long-term. The impact on the monopolization of the domestic market and the government's ability to manage the economy are other major concerns. More importantly, there is growing concern about sustainability in the negotiation of international investment agreements. UAE authorities are concerned that investment agreements interfere with their sustainable development strategies. As the result, the government has recently revised bilateral treaty agreements, renegotiating old agreements, putting on hold the conclusion of any new agreements, and even terminating several existing agreements, particularly in petroleum, military projects, and critical infrastructure. In addition, the country fears that the exploitation of natural resources and influence on trade relations with neighboring nations will soon see it lose its competitive advantage. The executives listed 12 concerns about the implications of influencing foreign investment in the UAE (Figure 3). In conclusion, $P 5$ is partly rejected.

P6: Significant regional and political risks exists that hinder technology transfer to the UAE.

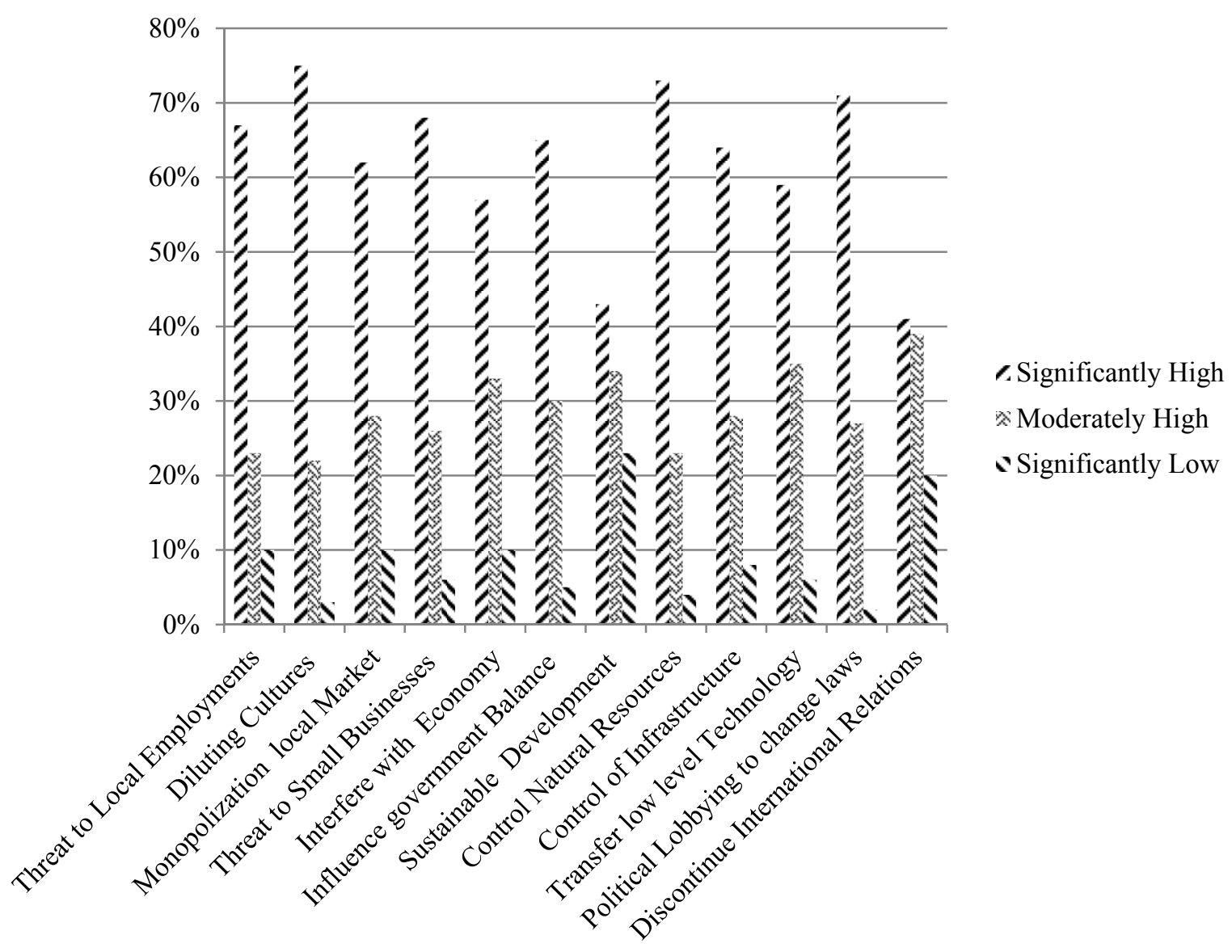

Figure 3. UAE concern issues about FDI

Political risks, which are the combination of the values and ideologies of most emerging nations inherited from 
their centralized economies, are the most challenging factor (Modarress et al., 2010; Dunning, 1993). Generally, investors fear that their enterprises may lose their competitive advantage by having a business in a conflict-zone economy. About $54 \%$ of respondents rated political challenges as significant. Those who have already invested in the UAE and are well aware of the country's politics, especially the geopolitical hotspots of Iran,Iraq, Kuwait, Bahrain, and Yemen as well as Egypt and Syria, stated that they have no plans to withdraw their investments from the UAE. Yet, they are unlikely to have future plans since their investments seem to be affected not only by the uncertain impact of political crises but also by military interventions. On the other hand, $32 \%$ of respondents rated the political risks as moderate and $14 \%$ rated them as low.

The executives also fear the Muslim Brotherhood's rise to power in the UAE when nearly 100 members of a local Islamist Al-Islah group were detained on charges of plotting a coup in April 2013. This was the second time in 2013 that the authorities had reported a specific threat from this Islamist militant group. In December 2012, UAE security forces arrested a cell of UAE and Saudi Arabian citizens which were planning attacks in both countries and other states, according to state news agency WAM. The UAE is also at risk of being caught up in any military conflict over Iran's disputed nuclear program, while Dubai is under pressure to limit its trade links with Iran. Any heightened tension in the Iran nuclear dispute or more sanctions on Iran could affect the UAE's economy. In addition, this makes the country a potential target for hosting several US military facilities (Kelly \& Stansfield, 2013).

In the interviews, the executives highlighted the regional environment as a key area of concern and supported the hypothesis that significant political risks are involved in investments in the UAE (PO). The executives insisted that manifestations of political risk should be calculated in any foreign investment in this region. They added that although the country has escaped the serious regional unrest that has shaken the Arab world, it is still struggling to insulate itself from regional disruptions. Indeed, this region has undergone several political transformations and challenges and these might continue in the future.

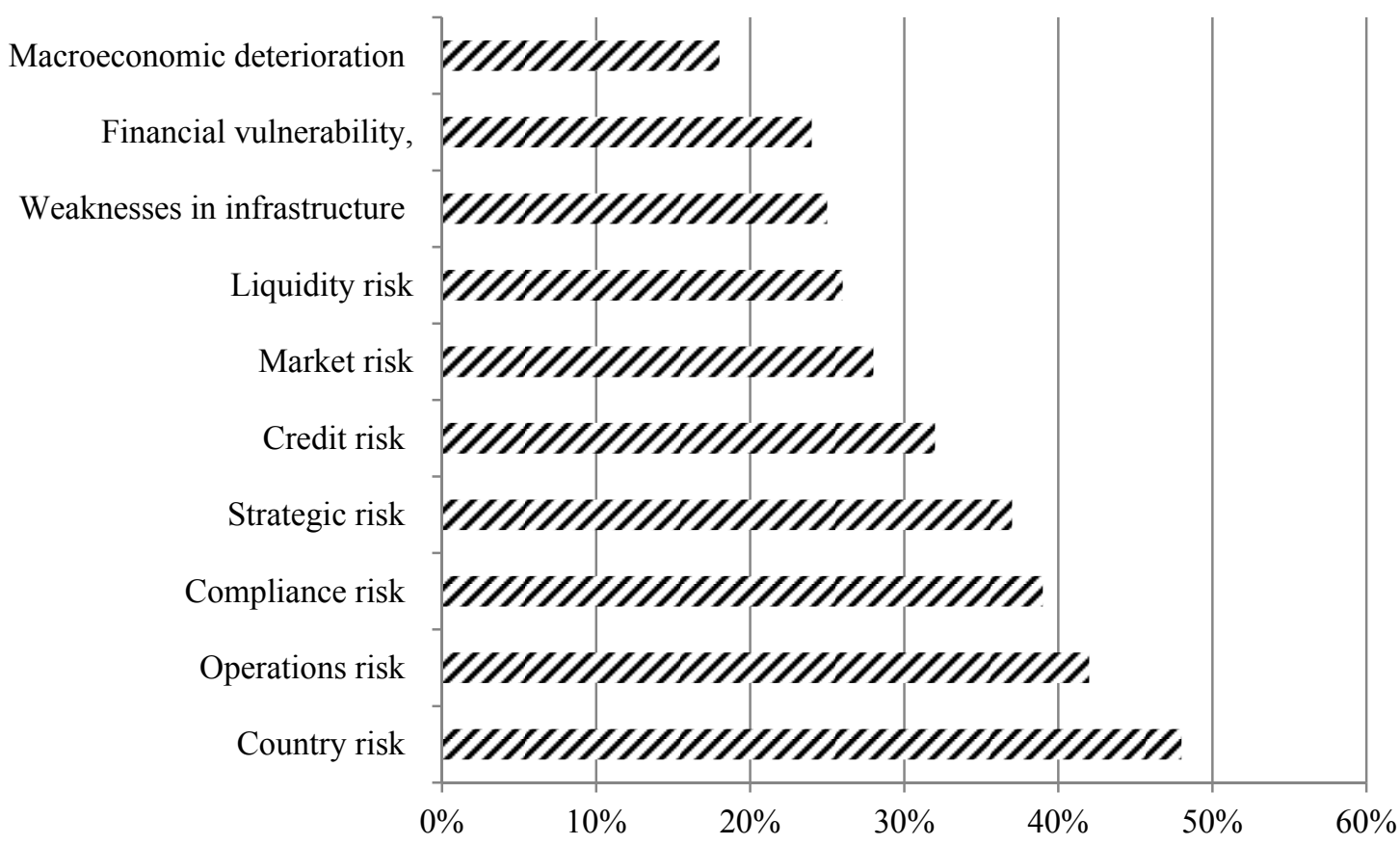

Figure 4. Regional risks of technology transfer through FDI

According to the Federal Deposit Insurance Corporation (2003), eight areas of risk are associated with FDI activities in this region. These risks, in order of importance, are: 1. Country risk, namely political and socioeconomic factors; 2. Operations risk, deficiencies in information systems or internal controls; 3 . Compliance risk, offshore vendors having inadequate privacy regulations and compliance with and the appropriateness of investment policies and procedures; 4. Strategic risk, a lack of government protection; 5. Credit risk, an issuer or counterparties fail to perform on an obligation to the investor; 6. Market risk, financial 
condition resulting from adverse changes in the value of holdings arising from movements in interest rates, foreign exchange rates, equity prices, or commodity prices; 7. Liquidity risk, an institution cannot easily sell, unwind, or offset a particular position at a fair price because of inadequate market depth; and 8. Legal risk, contracts are not legally enforceable. The majority of respondents (47\%) rated the country risk as the highest risk in the UAE, followed by $42 \%$ for operations risk, $39 \%$ for compliance risk, $37 \%$ for strategic, $32 \%$ for credit, $28 \%$ for market, $26 \%$ for liquidity, $25 \%$ for weakness in infrastructure, $23 \%$ for financial vulnerability, and $18 \%$ for macroeconomic deterioration (Figure 4).

\section{Summary}

Today, corporate structures are clustered around a multitude of cross-border connections to diverse businesses. This reflects the growing complexity of business decision making in which the traditional make-or-buy decision is intertwined with FDI and OS. Although these two strategies have been widely implemented for more than two decades, little is known about their differences. Reviewing the literature clearly points to 10 differences between FDI and OS. First, foreign investment is a business venture involving a long-term relationship, while OS relates to contracting out internal businesses to third-party organizations. Second, FDI is a category of asset that reflects a resident enterprise in one economy (direct investor) investing in another economy, whereas OS is the manifestation of the increased fragmentation of existing standard products and services into their constituents relocated to a foreign company. Third, the corporate structure of FDI operates outside the country but the corporate structure of OS resides in the home country. Fourth, foreign investment ownership and control is strongly associated with the percentage of investment (minimum 10\%), whereas OS has no control over suppliers in the host country. Foreign investors also have legal rights to patented products, trademarks, and equity capital as well as technical and managerial services in the host country, while these rights are not granted with OS. Fifth, the relationship of foreign investments with overseas partners is inundated with regulations linked to the legal framework of the host nation and the country's contractual incompleteness. Therefore, the final goods product and efficiency gained from OS is clearly preferred. Sixth, OS decisions are based on operating costs, which are explicitly driven by transferring them to entities beyond the perimeter of the principal organization, whereas all operating costs are shared by multinational corporations under foreign investment. In particular, HFDI reduces costs by investing, yet duplicating, its home-based products and processes in the same value chain stage in a host country. Seventh, while FDI flows are bidirectional (inward or outward), the flow of resources is one way from the vendor to the supplier with OS. Eighth, assets are easily transferred to the host country, whereas an OS arrangement does not involve transferring assets. Ninth, the bargaining power of multinational corporations is higher under FDI in comparison with OS. Tenth, the resilience of FDI during global financial crises is much higher compared with OS.

This striking feature of FDI has laid the foundation for shifting the perspectives of 54,000 transnational corporations to developing nations, which now have $\$ 3.4$ trillion invested in about 449,000 foreign affiliates throughout the world. From 1993 to 1998, the share of developing nations' world FDI inflows increased to 35.3\% compared with an average of $31.2 \%$ from 1988 to 1992 . Moreover, FDI flows to developing economies remained relatively strong in 2012, reaching $\$ 684$ billion, meaning that developing economies absorbed an unprecedented $\$ 130$ billion more than developed countries.

Since 2005, FDI has gained momentum in the Middle East and has gained the largest share of total FDI value globally. The Middle East attracted 6,740 projects worth $\$ 809.6$ billion, contributing to the creation of more than 1.1 million jobs between 2003 and 2010. Of the Middle East countries, the UAE was the largest destination for FDI projects. Between 2003 and 2010, the UAE attracted 44\% of projects, has $19.6 \%$ of the FDI value, and accounts for $30.6 \%$ of the jobs created. In 2011, the UAE attracted 368 FDI projects, the highest in the Middle East, registering an increase of $13.9 \%$ compared with 2010 . These projects created 22,166 jobs in the country, which is the highest in the Middle East.

The UAE's attractiveness as an FDI destination stems from many factors including its petroleum resources, infrastructure, a relatively stable economy, and about nine million multicultural expatriates. Nevertheless, a number of imperative questions have remained unanswered. Our interviews with 12 public and private sector executives involved with FDI and OS decisions and implementation were used to provide objective answers to the questions regarding attracting investors to UAE. These questions were as follows:

1). How can we bridge the gap between existing technology and new technology transferred by foreign investors?

2). Does the transferred technology have a positive impact on human capital formation?

3). Does enhanced human capital formation reduce income inequality? 
4). Does a government positively influence the transfer of new technologies?

5). Is there a high level of consensus among government authorities regarding technology transfer?

6). Does a significant regional-political risk hinder the transfer of new technologies?

The executive interviews and survey allowed us to draw the following conclusions. First, although there are significant differences between existing technology and the technology transfer $(P l)$ required by foreign investors, the technology has improved exponentially during the past decade. Furthermore, all executives commented that disparity among technologies requires four steps in improving the existing technology structure: developing a primary roadmap, identifying the product that will be the focus of the roadmap, and periodically reviewing and updating the technology and procedures. Second, technology transfer has a positive impact on human capital formation $(P 2)$. Third, technology transfer and the formation of human capital do not reduce income inequality in the UAE (P3). Fourth, the UAE government's investments, laws, and regulations are evolving and they are expected to become more conducive to foreign investment. The executives listed 14 factors that positively influence FDI and OS in the UAE. However, they also listed 25 factors that hinder foreign investment. Therefore, some degree of unease definitely exists among UAE authorities regarding technology transfer. Sixth, some political risks exist (P6); however, the large market potential coupled with investment in infrastructure and abundant natural resources make UAE a natural choice for consideration by foreign investors.

Overall, the respondents commented that the UAE government's incentives attract foreign investment to those areas where job opportunities, education levels, or standards of living are lagging. However, they are concerned about the implications of having international investment agreements that lay down common standards for national investment policies and that require each signatory to be bound to its rules.

\section{References}

Altomonte, C., \& Bonassi, C. (2004). FDI, International Outsourcing and Linkages. CESPRI Working Paper, Centre for Research on Innovation and Internationalisation Processes, Universita' Bocconi, Milano, Italy. Retrieved from http://econpapers.repec.org/paper/cricespri/wp155.htm

Baldwin, R., Braconier, H., \& Forslid, R. (1999). Multinationals, Endogenous Growth and Technological Spillovers: Theory and Evidence. Centre for Economic Policy Research.

Barney, J. (2010). Gaining and Sustaining Competitive Advantage (4th ed.). New York, NY: Pearson.

Blinder, A. (2009). Offshoring: Big Deal, or Business as Usual? In B. M. Friedman (Ed.), Offshoring of American Jobs: What Response from U.S. Economic Policy? (pp. 19-59). Cambridge, MA: MIT Press.

Boeing. (2013). Who Wins in Outsourcing? Retrieved from http://www.Boeing.com

Clark, J. (2004). Dissolving the Public Realm? The Logics and Limits of Neo-liberalism. Journal of Social Policy, 33(1), 27-48. http://dx.doi.org/10.1017/S0047279403007244

Dickinson, S. (2005). Outsourcing in China: Five Basics for Reducing Risk. Retrieved from http://www.ezinearticles.com

Dunning, J. (1993). Multinational Enterprises and the Global Economy. Addison-Wesley Publishing Company, Boston, MA.

Eisenhardt, M. (1987). Building Theories from Case Study Research. Academy of Management Review, 4(4), 532-550.

Ernst Young's Attractiveness Survey. (2012). Shifting Perspectives.

Federal Deposit Insurance Corporation. (2003, 2012, 2013). Retrieved from http://www.ey.com

Feenstra, R. (1998). Integration of Trade and Disintegration of Production in the Global Economy. Journal of Economic Perspectives, 12(4), 31-50. http://dx.doi.org/10.1257/jep.12.4.31

Gandolfi, F. (2009). Phases of Cost Cutting: Downsizing is Dead; Long Live the Downsizing Phenomenon. Review of International Comparative Management, 10(5), 864-876.

Glaser, G., \& Strauss, L. (1967). The Discovery of Grounded Theory: Strategies for Qualitative Research. Chicago: Aldine.

Grossman, G., \& Helpman, E. (2002) Integration versus Outsourcing in Industry Equilibrium. Quarterly Journal of Economics, 117(1), 85-120. http://dx.doi.org/10.1162/003355302753399454

Grossman, G., \& Helpman, E. (2003). Outsourcing versus FDI in Industry Equilibrium. Journal of the European 
Economic Association, 1(2-3), 317-327. http://dx.doi.org/10.1162/154247603322390955

Grossman, G., \& Helpman, E. (2005). Outsourcing in a Global Economy. Review of Economic Studies, 72, 135159. http://dx.doi.org/10.1111/0034-6527.00327

Harrison, B. (1994). Lean and Mean: The changing Landscape of Corporate Power in the Age of Flexibility. New York: Basic Books, Edward Elgar Publishing.

Hein, S. (1992). Trade Strategy and dependency Hypothesis: A Comparison of Policy, Foreign Investment, and Economic Growth in Latin America and East Asia. Economic Development and Cultural Change, 40(3), 495-521. http://dx.doi.org/10.1086/451958

Helpman, E. (1984). A Simple Theory of International Trade with Multinational Corporations. Journal of Political Economy, 92(3), 451-471. http://dx.doi.org/10.1086/261236

Hornberger, K., Battat, J., \& Kusek, P. (2011). Attracting FDI. World Bank, International Finance Corporation.

International Monetary Fund. (2011). Retrieved from http://www.imf.org

Kearney Global Foreign Direct Investment Confidence Index. (2013). Retrieved from http://www.atkearney.com

Kelly, A., \& Stanfield, G. (2013). International Affairs, 89(5), 1203-1219. http://dx.doi.org/10.1111/1468-2346.12067

Kokko, A. (1996). Productivity Spillovers from Competition between Local Firms and Foreign Affiliates. $\begin{array}{llll}\text { Journal of International Development, } & 8(4), & 517-530 .\end{array}$ http://dx.doi.org/10.1002/(SICI)1099-1328(199607)8:4<517::AID-JID298>3.0.CO;2-P

Levina, N., \& Ross, J. (2003). From the Vendor's Perspective: Exploring the Value Proposition in Information Technology. MIS Quarterly, 2(3), 331-364.

Lim, S. (2005). Foreign Investment Impact and Incentive: a Strategic Approach to the Relationship between the Objectives of Foreign Investment Policy and their Promotion. International Business Review, 14(1), 61-76. http://dx.doi.org/10.1016/j.ibusrev.2004.12.004

Lin, K., \& Tomaskovic-Devey, D. (2011). Financialization and US Income Inequality, 1970-2008. American Journal of Sociology, 118(5), 1284-1329. http://dx.doi.org/10.1086/669499

Loh, H., \& Venkatraman, N. (1995). An Empirical Study of Information Technology Outsourcing: Benefits, Risks, and Performance Implications. Proceedings of the Sixteenth International Conference on Information Systems. Amsterdam, 277-288.

Lonsdale, C., \& Cox, A. (2000). The Historical Development of Outsourcing: The Latest Fad? Industrial Management \& Data Systems, 100(9), 444-450. http://dx.doi.org/10.1108/02635570010358384

Lowe, J., \& Taylor, P. (1998). R\&D and Technology Purchase through License Agreements: Complementary Strategies and Complementary Assets. R\&D Management, 28(4), 263-278. http://dx.doi.org/10.1111/1467-9310.00103

Markusen, J. (1984). Multinationals, Multi-Plant Economics, and the Gains from Trade. Journal of International Economics, 16(3-4), 205-526. http://dx.doi.org/10.1016/S0022-1996(84)80001-X

Markusen, J. (1995). The Boundaries of Multinational Enterprises and the Theory of International Trade. The Journal of Economic Perspectives, 9(4), 169-189. http://dx.doi.org/10.1257/jep.9.2.169

Markusen, J., \& Venables, A. (1996). Multinational Production, Skilled Labor and Real Wages. Working Paper 5483. National Bureau of Economic Research. Cambridge, Cambridge University Press.

Markusen, J., \& Venables, A. (1998). Multinational Firms and the New Trade Theory. Journal of International Economics, 46, 183-203. http://dx.doi.org/10.1016/S0022-1996(97)00052-4

Markusen, J., \& Venables, A. (1999). Foreign Direct Investment as a Catalyst for Industrial Development. European Economic Review, 43(2), 335-356. http://dx.doi.org/10.1016/S0014-2921(98)00048-8

Modarress, B., \& Ansari, A. (1990). Two Strategies for Regaining the US Manufacturing Dominance. International Journal of Quality and Reliability Management, 7(6), 68-77. http://dx.doi.org/10.1108/02656719010003677

Modarress, B., \& Ansari, A. (2007). The Economic, Technological, and National Security Risks of Offshore Outsourcing. Journal of Global Business Issues, 1(2), 165-175.

Modarress, B., \& Ansari, A. (2008). Offshore Outsourcing Strategy in the U.S. Aircraft Industry. International 
Journal of Global Business and Economics, 1(1), 76-81.

Modarress, B., Ansari, A., \& Lockwood, D. (2010). Outsourcing Logistics to Tthird-Party Providers: Practitioners Perspectives. International Journal of Logistics Systems and Management, 6(1), 23-38. http://dx.doi.org/10.1504/IJLSM.2010.029719

Modarress, B., Ansari, A., \& Lockwood, D. (2013). Emiratization: from Policy to Implementation. International Journal of Human Resources Development and Management, 13(2), 188-205. http://dx.doi.org/10.1504/IJHRDM.2013.055395

Modarress, B., Ansari, A., \& Thies, E. (2012). The Effect of Transnational Threats on the Security of Persian Gulf maritime Petroleum Transportation. Journal of Transportation Security, 5(3), 169-186. http://dx.doi.org/10.1007/s12198-012-0090-y

New York State Department of Labor and Empire State Development. (2010).

Palugod, N., \& Palugod, P. (2011). Global Trends in Offshoring and Outsourcing. International Journal of Business and Social Science, 2(16), 13.

Philip, S., Silberglitt, R., \& Schneider, J. (2001). The Global Technology Revolution. Rand Defense National Institute.

Prabhakar, R. (2012). Shifting Perspectives: Middle East Special edition for the Growing beyond Summit 2012, 16 and 17 October, Ernst \& Young's survey. Tata Consultancy Services-Revenue Analysis \& Operating Metrics 2006-2011, May 01, 2011.

Reed, T. (2005). The hidden risk in outsourcing overseas. Retrieved from http://www.news.com

Schaltegger, S., \& Wagner, M. (2011). Sustainable Entrepreneurship and Sustainability Innovation: Categories and Interactions. Business Strategy and the Environment, 20(14), 222-237. http://dx.doi.org/10.1002/bse.682

Schultz, T. (1961). Investment in Human Capital. American Economic Review, 51(1), 1-17.

Schultz, T. (1975). The value of the Ability to Deal with Disequilibria. Journal of Economic Literature, 13(3), $827-846$.

Sheikh Mohammed Bin Rashid Al-Maktoum Office. (2013). Dubai, UAE.

The UAE Department of Labor. (2012). United Arab Emirates.

The UAE Ministry of Finance and Industry. (2008).

Tong, H., \& Wei, S. (2011). The Composition Matters: Capital Inflows and Liquidity Crunch During a Global Economic Crisis. Review of Financial Studies, 24(6), 2023-2052. http://dx.doi.org/10.1093/rfs/hhq078

United Nation Conference on Trade and Development (UNCTAD). (2008). World Investment Report: Transnational Corporations, and Infrastructure Challenge, New York and Geneva. Retrieved from http://www.unctad.org

United Nation Conference on Trade and Development (UNCTAD). (2010). World Investment Report. New York. Retrieved from http://www.unctad.org

United Nation Conference on Trade and Development (UNCTAD). (2011). Global Investment Trends Monitor. No. 5, January 17. New York and Geneva, 2011. Retrieved from http://www.unctad.org

United Nation Conference on Trade and Development (UNCTAD). (2012). Global Trend Monitor. Retrieved from http://www.unctad.org

United Nations Conference on Trade and Development (UNCTAD). (2011). Foreign Direct Investment, the Transfer and Diffusion of Technology, and Sustainable Development. Geneva, February 16-18. Retrieved from http://www.unctad.org

United Nations Development Programme (UNCTAD). (2012). Toward Human Resilience: Sustaining Millennium Development Goals Progress in an Age of Economic Uncertainty. Retrieved from http://www.unctad.org

United Nations. (2012). Global Investment Trend. No. 8. Retrieved from http://www.un.org

United States Department of Commerce (USDC). (2010). Bureau of Economic Analysis. Retrieved from http://www.bea.gov 
Willem te Velde, D. (2001). Government Policies Toward Inward Foreign Direct Investment in Developing Countries: Implications for Human Capital Formation and Income inequality. OECD Development Centre, December.

World Bank Group. (2011). Investing Across Borders. Retrieved from http://www.worldbank.org

World Bank. (2009). World Development Indicators Database. Retrieved from http://www.worldbank.org

Yin, R. (1984). Case Study Research: Design and Methods. Beverly Hills, CA: Sage Publishing.

\section{Copyrights}

Copyright for this article is retained by the author(s), with first publication rights granted to the journal.

This is an open-access article distributed under the terms and conditions of the Creative Commons Attribution license (http://creativecommons.org/licenses/by/3.0/). 